\title{
Perceived Roles of Ethics and Social Responsibility, Internal Corporate Social Responsibility and Employee Engagement of Academicians
}

\author{
Low Mei Peng" \\ Universiti Tunku Abdul Rahman, Malaysia \\ Choe Kum Lung \\ Universiti Tunku Abdul Rahman, Malaysia \\ Lau Teck Chai \\ Universiti Tunku Abdul Rahman, Malaysia
}

\begin{abstract}
The echo of Corporate Social Responsibility (CSR) is often heard in the contemporary business management since the last four decades. CSR continuously getting attention due to the ever changing business landscape. As CSR marks its notion of importance in the business context, its roles, and values among academicians who are entrusted to educate the future generation remains ambiguous. Current research aims to look into the impact of perceived roles of ethics and social responsibility (PRESOR) and Internal CSR on the Employee Engagement among academicians in the education setting. Judgemental sampling method is used to locate the targeted respondents and data collected is analysed using Partial Least Squares Equation Modeling. The results reveal that PRESOR has a positive impact on Internal CSR. Internal CSR has no significant impact on Employee Engagement among academicians and its' indirect effect between PRESOR and Employee Engagement is also found to be insignificant. The findings contribute by providing some insights on the role of ethics and social responsibility among academicians in the education sector. Education institutions may wish to look into other means to increase academicians' employee engagement instead of ethics and social responsibility.
\end{abstract}

Keywords: Investment processes; Investment dynamics; Structural changes.

(c) (1) CC BY: Creative Commons Attribution License 4.0

\section{Introduction}

Corporate Social Responsibility (CSR) has been receiving increasing attention since its inception in the 1950s. The rationale for the perpetual attention is due to the agile business environment, which continuously shapes the definition and the progressing understanding of CSR. Traditionally, CSR is discussed in the business-related context such as its relationship with business performance, business attractiveness and business strategies. Scare research is conducted in the non-business setting such as education among academics. According to United Nations Educational, Scientific and Cultural Organisation (UNESCO), education is a mean to empower both children and adults in becoming active participants in the transformation of the society. The process of education involves learning that focus on the values, attitudes, and behaviours which enable individuals to learn to live together in a world characterised by diversity and pluralism. This indicates that education and academicians have a novel role to play in shaping and changing the future generation as well as the society. As the role of education and academician are significantly important, it is of interest to study the values of ethics and social responsibility being practiced among academician in education sector too.

The research paper aims to contribute to understand the impact of Perceived Role of Ethic and Social Responsibility (PRESOR) toward Internal CSR practices and examining the role of Internal CSR practices on academicians' employee engagement. The research paper also undertakes to study the indirect effect of Internal CSR practices between PRESOR and Employee Engagement in the education context. The findings of this research would add values to the body of knowledge in the context of the role of ethics and social responsibility together with Internal CSR practices among academicians in the education setting. This research paper is organised into seven sections with the first section purveying the background of the study, followed by the literature review, research framework, research methodology, data analysis, findings, and discussions; and end with limitations and future research.

\section{Literature Review}

\subsection{Background of Study}

Acknowledging the intense global competition worldwide together with the evolvement of Malaysia economy toward a knowledge-based economy, education has an even more crucial role to play. Knowledge-based economy is defined as an economy in which knowledge, creativity, and innovation play an ever-increasing and important role in generating and sustaining growth (Anon, 2017). Malaysia Government is placing a high emphasis on increasing 
accessibility to higher education to produce a critical mass of trained, skilled, and knowledgeable workforce that would sustain economic growth, increase competitiveness, and support a knowledge-based economy. This effort is observed in the amendment to the Education Act in 1995 that led to the introduction of the Private Higher Education Act 1996. As a result, the number of higher education institutions are springing up like mushrooms after rain. According to Ministry of Higher Education, Malaysia had 20 public universities and 43 private universities, 31 private university colleges and 9 foreign university branches as at 2015 .

The increasing number of higher learning institutions is also translated into the intense rivalry among them. Universities are setting new challenging goal to compete with their counterparts and the academic staff is involved in achieving the ultimate goal of their respective universities. In this regard, the academician is shouldered with more tasks other than to impart knowledge to the future generation. The academician's responsibilities are expanded to heavy teaching loads, community-based research, and professional service responsibilities may constitute an overwhelming set of role expectations (Bochenek et al., 2002). This put the academician in tremendous stress and subsequently affect their job satisfaction and even their physical as well as mental health. Workplace stressors often have detrimental effects on faculty staff's job satisfaction and subsequently negatively affect the university. Current research endeavours to examine the role of ethics and social responsibility among the academicians in the higher learning institutions in discharging their multiple responsibilities yet exhibiting a high level of employee engagement.

\subsection{Ethics and Social Responsibility}

An increased concern in ethical and social responsibility in businesses around the globe has brought ethical and social responsibility research to the higher level (Singhapakdi et al., 2001). Due to the different country environment businesses faced, there exists a wide divergence in the level of importance of ethics and social responsibility. Majority of the differences exist from country to country in the economic development, cultural standards, legal/political systems, and expectations regarding business conduct (Wotruba, 1997). Nevertheless, there are some overlaps in terms of definition between ethics and social responsibility. Carroll (1999) explained that new definition of concepts emerges in the 1980s as a result of more advanced empirical research. The variation includes business ethics, stakeholder theory, stakeholder management, corporate social responsibility, corporate social performance as well as corporate social responsiveness that surfaced lately. Often than not, ethics is defined as the fundamental principle that generates actions to prevent substantial harm to others, when an individual or group has the chance to do so for their own benefit (Boddy, 2011). Social responsibility is an ethical framework, which suggests that an entity, be it an individual or organisation, has an obligation to act for the benefit of society at large. Every individual's duty to act so as to maintain a balance between the economy and society is considered as social responsibility. An individual's moral standard is based on individual's perception as to whether it can hurt or severely benefit another (Churchill, 1982). This individual's perception relates to one's perception of ethics and social responsibility (PRESOR) while at work in carrying out their task. Singhapakdi et al. (1996) claimed that managers must first perceive ethics and social responsibility as important for business success before they will behave in an ethical and socially responsible way. Yin et al. (2016) pointed that research on PRESOR is subtle. It is worthwhile to explore on PRESOR research. Hence, the focus of this research is PRESOR and Internal CSR practices, whereby Internal CSR represents the stakeholder's aspect of CSR in the education setting.

\subsection{Perceived Roles of Ethics and Social Responsibility (PRESOR)}

Referring to the structure of belief systems in a society, perceptions are social phenomena that constitute or inform the mental models of every individual. It is empirically proven that an individual must first perceive ethics and social responsibility as important for every endeavour before they will behave in an ethical and socially responsible manner (Vitell et al., 2010); (Vitell and Joseph, 2004). It is believed that the management's values and beliefs can act as a guide in recognising and evaluating social issues and the salience of stakeholders. This also denotes that an appreciation of the role of ethics and social responsibility for any individuals be it an employee or manager would affect organisational effectiveness.

Singhapakdi (1999) was the pioneer researcher who developed the measurement scale for PRESOR that includes general statements about the importance of ethics and social responsibility as determinants of an organisation's overall effectiveness and efficiency. Past studies have indicated that PRESOR scales cover three dimensions, namely stakeholder view, compatibility view and stockholder view (Axinn et al., 2004); (Shafer et al., 2007). Shafer et al. (2007) explained that the stakeholder view reflects the importance of ethics and social responsibility to organisational survival and success. Shafer et al. (2007) added that the stakeholder view is broader and longer-term perspective of corporate obligations which is analogous to Singhapakdi et al. (1996) long-term gains. As for the compatibility view, Shafer et al. (2007) explained that it reflects the compatibility of ethics and social responsibility with business success. According to them, the stockholder view reveals a limited and narrow aspect of corporate obligations which is the emphasis on profitability and obligations only to stockholders. This stockholder view is comparable to Singhapakdi et al. (1996) as short-term gains. Conceptually, this view reflects the individual's tendency of believing ethics and social responsibility are also important in achieving short-term gains.

Drawing from the scarcity of PRESOR research in the education setting and the challenges encountered by higher learning institutions, present research aims to examine the role of PRESOR in the practice of Internal CSR as well as its' impact on employee engagement among academicians. 


\subsection{Internal Corporate Social Responsibility (CSR)}

Ever since the discussion of CSR started, CSR had undergone massive evolution. According to Low (2015) its' focus had expanded to stakeholders since the late 2000s. CSR practices in the stakeholders' aspect for employees cover areas such as employee's safety, health and well-being, work-family relationship, training and involvement in the business and equal opportunities Vives (2006). More recently, society has identified ethics, quality of work life, and job satisfaction as the intervening factors that would determine the competitiveness of an organisation when it comes to providing benefits to stakeholders Kalayanee et al. (2010). In view of the challenges faced by academicians in the intense competitive environment, it is deemed timely to investigate the impact of Internal CSR practices in the education context. However, due to the past CSR related research are heavily focused on the external aspect, the term Internal CSR suffered from a well-established definition.

Turker (2009b) initiated the research on describing internal CSR activities and developing the measurement scale for internal CSR. According to (Turker, 2009a;2009b), Internal CSR activities are activities directly related to the employees' physical and psychological working environment. Recently, a research by Mory et al. (2016) adopted (Turker, 2009a;2009b) definition of internal CSR to gauge its' impact on employees' organisational commitment in the pharmaceutical company located in German. Mory et al. (2016) used five dimensions to measure Internal CSR practices, i.e., Training and Development, Human Right, Health and Safety, Workforce Diversity, and Work-Life Balance. For the current research, these five dimensions are adopted to understand the impact of Internal CSR practices among academician's employee engagement and its indirect effect between PRESOR and employee engagement.

\subsection{Employee Engagement}

The concept of employee engagement emerged in the late $20 \mathrm{~s}$ as a human resource element that relates to profitability through higher productivity, sales, customer satisfaction and employee retention (Hewitt Associates, 2005). Macey and Schneider (2008) informed that the meaning of engagement is derived from the practice and research-driven literature, which is attributed to folk theory. Folk theory of mind operates prior to any particular conscious or unconscious cognition and provides the frame or interpretation of that cognition (Malle, 2003). To simplify the understanding of folk theory, it is about the intuitive sense that people, especially leaders within organisations have about work motivation. Macey and Schneider (2008) then defined employee engagement as a desirable condition that consists of an organisational purpose and connotes involvement, commitment, passion, enthusiasm, focused effort and energy. This explanation covers attitudinal and behavioural aspects. According to the framework for understanding employee engagement developed by Macey and Schneider (2008) there are three elements, namely trait engagement, state engagement and behavioural engagement. They further explained that trait and state engagement are the attitudinal aspects that discuss positive views of life and work, and feelings of energy respectively. Behavioural engagement is the behavioural aspect that focuses on extra-role behaviour such as organisational citizenship behaviour (OCB), Proactive/ Personal Initiative, role expansion and adaptive.

The current research attempts to explore the role of PRESOR and Internal CSR practices in private universities with no emphasis on extra-role behaviour. Hence, only the attitudinal aspect is investigated as to establish how PRESOR and Internal CSR practices affected the attitude of academicians. The following subsections provide an overview of trait and state engagement.

\subsection{Trait Engagement}

Macey and Schneider (2008) explained that trait engagement is an inclination to experience the world from a particular standpoint such as positive affectivity by feelings of enthusiasm. It is reflected in psychological state engagement which involves positive views of life and work. Drawing from Macey and Schneider (2008) employee engagement framework, the components of trait engagement are proactive personality, autotelic personality, trait positive affect, and conscientiousness. They explained that trait engagement is attributed to Positive Affectivity trait which serves as an orientation to frame organisational experiences and thereby determine how the individual behaves in response to those experiences (Larsen et al., 2002); Weiss (2002). This matches the objective of the research to investigate the experiences of PRESOR and Internal CSR practices among academicians.

\subsection{State Engagement}

State engagement is feelings of energy which comprises of satisfaction, involvement, commitment and empowerment as per (Macey and Schneider, 2008) employee engagement framework. Erickson (2005) agreed with (Macey and Schneider, 2008) views that engagement is more than simple satisfaction with employment arrangement, but it is also about passion and commitment displayed by the employee through their willingness to devote themselves to help the employer succeed. In short, state engagement covers older constructs such as job satisfaction, organisational commitment, job involvement, feelings of empowerment as well as the focus of affection that was not measured previously. The affective native of state engagement distinguishing itself from the older constructs that positioned positive affectivity as midway between the positive end of the activation dimension and the pleasant end of the hedonic valence dimension. From the measurement perspective, the questionnaire items capture constructs similar to involvement and satisfaction but with additional emotional, energetic affective tone such as "At work, I feel bursting with energy." In addition, state engagement construct proposes an emphasis on the independent construct which is of Industrial-Organisational focus. As such, trait and state engagement are adopted as 
the endogenous variable to understand the role of PRESOR and Internal CSR practices among academicians in education settings.

\section{Research Framework and Hypotheses}

Against the background purveyed, the following research framework is developed to carry out the research objectives set forth:

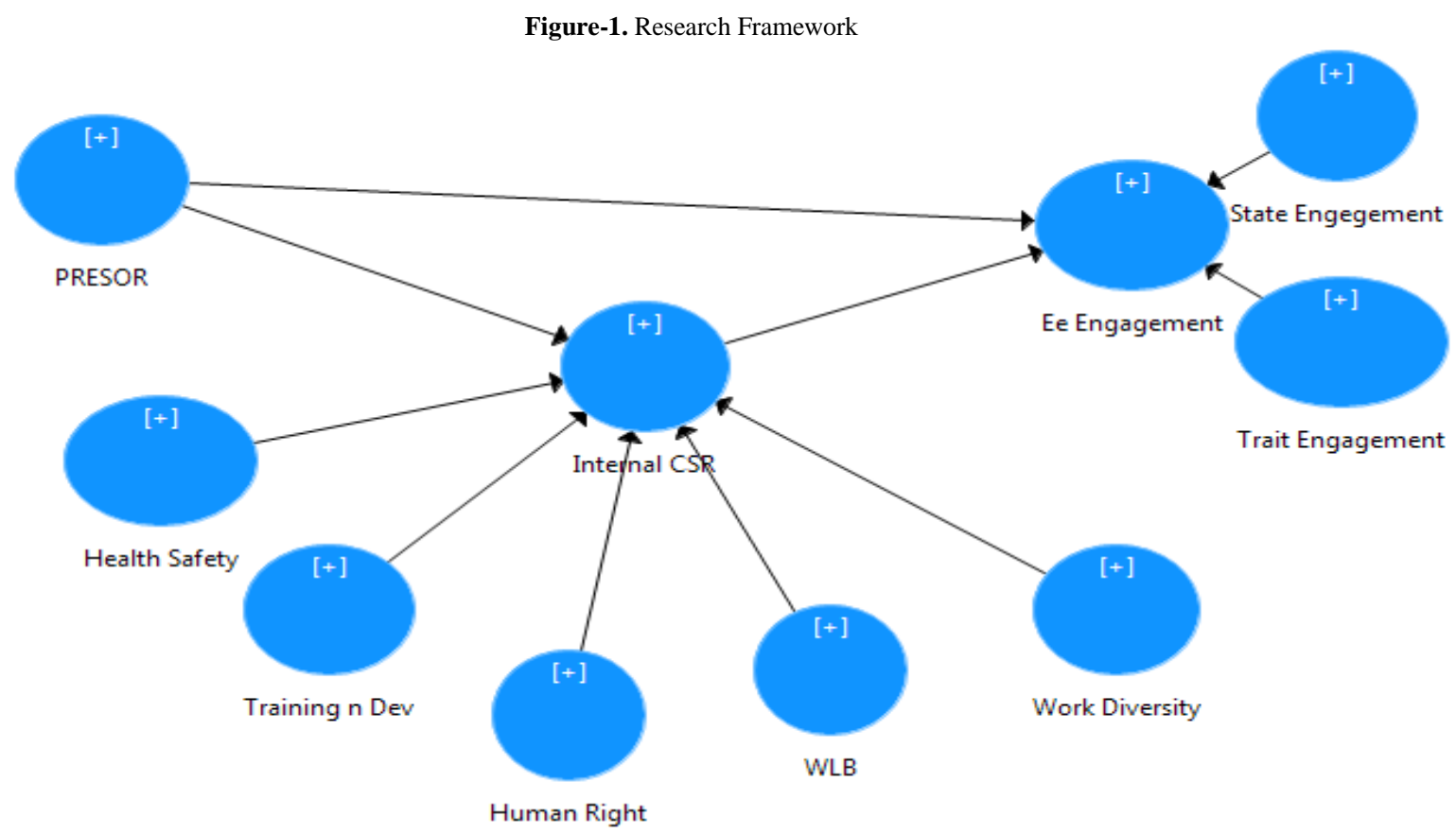

PRESOR is the exogenous variable in this research while Internal CSR and Employee engagement are the endogenous variables. PRESOR is the first-order component which is considered as single layer of constructs while Internal CSR and Employee Engagement are regarded as hierarchical component models (HCMs). HCMs involve testing second-order structures that consist of two layers of components (e.g., (Ringle et al., 2012) (Wetzels et al., 2009). The rationale for using HCMs is to provide more parsimony and reduces the complexity of the model. There are five dimensions used to measure Internal CSR, i.e., Health and Safety, Human Right, Work Diversity, Work-Life Balance and; Training and Development. For the endogenous variable of Employee Engagement, it captures State Engagement and Trait Engagement by subscribing to Macey and Schneider (2008) Macey and Schneider (2008)'s framework.

The issue of ethics has becomes a worldwide concern as a result of past-faced technology and global business expansion. There is an increased awareness of ethical and social responsibility that every organisation displays which could affect organisations performance, be it a profit oriented or not profit oriented organisation. The degree of divergence in ethical behaviour and attitudes of every organisation can be explained by, among other variables, differences in perceptions regarding the importance of ethics and social responsibility in achieving organisational effectiveness. Organisations which considered to have incorporated CSR orientation is comparable to have institutionalised ethics explicitly and/ or implicitly incorporated ethics into its decision making process. Hence, present research aims to investigate the impact of PRESOR on Internal CSR practices among academicians and the following hypothesis is formulated:

H1: PRESOR is positively associated with Internal CSR practices.

Articles (e.g. (Demirtas and Akdogan, 2015); (Singhapakdi et al., 2008); (Marta et al., 2004);(Singhapakdi, 1999) relating to perception of ethics and social responsibility pointed out that PRESOR influences on organisation' ethical intention. This research is interested to find out whether organisations which emphasise on ethics and social responsibility would have higher Employee Engagement. Employee engagement predicts importance employee outcomes such as organisational success and firm financial performance. (Bates, 2004); (Baumruk, 2004);(Harter et al., 2002);(Richman, 2006). With this, the following hypothesis is developed:

H2: PRESOR is positively associated with Employee Engagement.

Research on CSR and employee engagement is considered embryonic, but there are a few studies pointed out that there is a positive relationship between CSR and employee engagement. Glavas and Piderit (2009) found that the effect on employee engagement resulting from positive employees' perceptions of CSR was strengthened by the importance of CSR. In addition, the development of CSR has expanded its focus to the stakeholder (Low, 2015) which marks the evolvement of Internal CSR, that concern of the physical and psychological well-being of employees. As such, this research hypothesises that Internal CSR would produce higher Employee Engagement as per the following hypothesis:

H3: Internal CSR is positively associated with Employee Engagement. 
In view of the discussion that PRESOR may determine the implementation of Internal CSR practice and PRESOR could produce higher Employee Engagement, it is of interest to investigate the mediating role of Internal CSR. Internal CSR is proposed to have an indirect relationship between PRESOR and Employee Engagement. Hence, the following hypothesis is formed:

H4: Internal CSR mediates the relationship between PRESOR and Employee Engagement.

\section{Research Methodology}

This is a quantitative research which uses questionnaire survey to capture the responses of targeted respondents. The non-probability judgemental sampling method was adopted in this research. Data were collected through an intercept survey by using self-administered questionnaire from private universities located in Peninsular Malaysia. G*power 3.1 (Faul et al., 2007; Faul et al., 2009); software was used to calculate the sample size required to ensure the model tested is statistically sound. Based on a power set at $80 \%$ (Gefen et al., 2011), $f^{2}=$ 0.05 (small), $\alpha=0.05$ and number of predictors $=2$, the sample size required was 210.300 sets of questionnaires were sent out and a total of 212 sets useable questionnaire were collected, yielding a $70.67 \%$ of response rate. Therefore, given that our sample size exceeds 210, and the minimum power required in social and behavioural science research is typically 0.8 , thus our sample size is arguably be deemed sufficient. In addition, because previous studies have identified a threshold of 100 samples for PLS-SEM analysis (Akter et al., 2011);(Reinartz et al., 2009) a sample size of 212 returned questionnaires would be considered as adequate.

The questionnaire was divided into 4 sections. Section A covers respondents' demographic profile. Section B includes information on PRESOR which the items was adapted from Singhapakdi et al. (1996). Section C consists of Internal CSR items that were adapted from (Turker, 2009a;2009b). Section D contains information pertaining to Employee Engagement adapted from Macey and Schneider (2008). Respondents were asked to indicate their agreement or disagreement with several statements on a five-point Likert scale ranging from $1=$ strongly disagree to $5=$ strongly agree.

Data collected was analysed using Partial Least Squares Structural Equation Modeling (PLS-SEM). PLS-SEM has emerged as a popular statistical software due to its ability to handle complex models that involve moderators and mediators which often the case of social sciences research. In fact, PLS-SEM is the second generation of statistical methods that enable the estimation of hierarchical latent variable and models, which meets the objective of the present research.

For the current research, the issue of common method variance had been addressed through procedural; and statistical remedy as proposed by Podsakoff et al. (2003). In terms of the procedural remedy, the measures of the constructs are collected from different sources and there are different scale adopted for different constructs. As for statistical remedy, Harman's single factor test informed that the first-factor account for 32.5\% variance which is less than the threshold level of 50.0\% of the total variance explained Podsakoff et al. (2003). It is concluded that present research does not suffer from common method variance.

\section{Results}

\subsection{Respondents' Profile}

Based on Table 1, the majority of the respondents are female with $52.8 \%$ while male respondents are $47.2 \%$. Most of the respondents are below the age of 35 which recorded at $50.9 \%$. In terms of marital status, it is about more than half of the respondents are single. Chinese respondents are the dominant among other ethnicities with $43.4 \%$, followed by Malays, $32.1 \%$ and Indian, 23.1\%. 44.8\% of the respondents have been working in the current universities for 4 years and less. There are $37.7 \%$ of the respondents have been working in their current universities for 5 to 10 years. Less than $20 \%$ of the respondents have been working for a decade with their current universities.

Table-1. Respondents' Profile

\begin{tabular}{l|c|c}
\hline Profile & Sample $(\mathbf{N}=\mathbf{2 1 2})$ & Percentage \\
\hline Gender & & \\
\hline Female & 112 & $52.8 \%$ \\
\hline Male & 100 & $47.2 \%$ \\
\hline \hline Age & & \\
\hline$<\mathbf{3 5}$ year old & 108 & $50.9 \%$ \\
\hline $\mathbf{3 5 - 4 4}$ & 65 & $30.7 \%$ \\
\hline $\mathbf{4 5 - 5 4}$ & 29 & $13.7 \%$ \\
\hline$>\mathbf{5 4}$ & 10 & $4.7 \%$ \\
\hline \hline Marital Status & & \\
\hline Single & 109 & $51.4 \%$ \\
\hline Married & 103 & $48.6 \%$ \\
\hline \hline Ethnic & & \\
\hline Malay & 68 & $32.1 \%$ \\
\hline Chinese & 92 & $43.4 \%$ \\
\hline Indian & 49 & $23.1 \%$ \\
\hline & &
\end{tabular}


The Journal of Social Sciences Research

\begin{tabular}{l|c|c}
\hline Others & 3 & $1.4 \%$ \\
\hline \multicolumn{2}{|c|}{ Working Experience } & \\
\hline 4 years and less & 95 & $44.8 \%$ \\
\hline 5-10 year & 80 & $37.7 \%$ \\
\hline 10 year above & 37 & $17.5 \%$ \\
\hline
\end{tabular}

\subsection{Measurement Model Analysis}

Before we proceed with the two-step analysis approach of PLS-SEM as suggested by Anderson and Gerbing (1988), multivariate skewness and kurtosis were assessed. According to Hair et al. (2017) and Cain et al. (2016), multivariate skewness and kurtosis could be assessed by using the software available at: https://webpower.psychstat.org/models/kurtosis/results.php?url=1817b2b456d49787b231636c4d76b8b3. The results showed that the data we have collected was not multivariate normal, Mardia's multivariate skewness $(\beta=17.098$, $p<$ $0.01)$ and Mardia's multivariate kurtosis $(\beta=149.312, \mathrm{p}<0.01)$. Hence, we proceeded to use SmartPLS which is a non-parametric analysis software.

The measurement model analysis consists of two types of validity, namely convergent validity, and discriminant validity. The assessment of convergent analysis is ascertained by examining the loadings, average variance extracted (AVE) and also the composite reliability (Gholami et al., 2013); (Rahman et al., 2015). The loadings were all higher than 0.6, the composite reliabilities were all above 0.7 and the AVE of all constructs were also higher than 0.5 as suggested in the literature, and exhibited in Table 2 and Figure 2. Items that below the recommended values had been removed in the scale refinement process, such as PRESOR 5, HR3, HS5, TD5, WD2, WLB1, Ee8, Ee12, Ee13, Ee14, and Ee15.

Table-2. Convergent Validity

\begin{tabular}{|c|c|c|c|c|c|c|c|}
\hline Construct & Indicator & Items & Loading & $\begin{array}{l}\text { Composite } \\
\text { Reliability } \\
\end{array}$ & $\begin{array}{l}\text { Cronbach's } \\
\text { Alpha }\end{array}$ & rho_A & AVE \\
\hline \multirow{4}{*}{ PRESOR } & PRESOR & PRESOR1 & 0.850 & 0.865 & 0.792 & 0.817 & 0.618 \\
\hline & & PRESOR2 & 0.816 & & & & \\
\hline & & PRESOR3 & 0.820 & & & & \\
\hline & & PRESOR4 & 0.640 & & & & \\
\hline \multirow{25}{*}{ Internal CSR } & Human Right & HR1 & 0.762 & 0.878 & 0.814 & 0.820 & 0.642 \\
\hline & & HR2 & 0.805 & & & & \\
\hline & & HR4 & 0.808 & & & & \\
\hline & & HR5 & 0.829 & & & & \\
\hline & Health \& Safety & HS1 & 0.798 & 0.881 & 0.831 & 0.834 & 0.596 \\
\hline & & HS2 & 0.794 & & & & \\
\hline & & HS3 & 0.772 & & & & \\
\hline & & HS4 & 0.734 & & & & \\
\hline & & HS6 & 0.761 & & & & \\
\hline & Training \& Dev & TD1 & 0.739 & 0.885 & 0.835 & 0.855 & 0.610 \\
\hline & & TD2 & 0.678 & & & & \\
\hline & & TD4 & 0.735 & & & & \\
\hline & & TD6 & 0.952 & & & & \\
\hline & & TD7 & 0.771 & & & & \\
\hline & Work Diversity & WD1 & 0.809 & 0.883 & 0.823 & 0.826 & 0.653 \\
\hline & & WD3 & 0.799 & & & & \\
\hline & & WD4 & 0.778 & & & & \\
\hline & & WD5 & 0.846 & & & & \\
\hline & $\begin{array}{|ll|}\text { Work } & \text { Life } \\
\text { Balance } & \\
\end{array}$ & WLB2 & 0.697 & 0.899 & 0.869 & 0.873 & 0.562 \\
\hline & & WLB3 & 0.815 & & & & \\
\hline & & WLB4 & 0.654 & & & & \\
\hline & & WLB5 & 0.732 & & & & \\
\hline & & WLB6 & 0.776 & & & & \\
\hline & & WLB7 & 0.765 & & & & \\
\hline & & WLB8 & 0.797 & & & & \\
\hline \multirow{6}{*}{$\begin{array}{l}\text { Employee } \\
\text { Engagement }\end{array}$} & \begin{tabular}{|l} 
State \\
Engagement
\end{tabular} & Ee3 & 0.673 & 0.846 & 0.772 & 0.815 & 0.528 \\
\hline & & Ee6 & 0.638 & & & & \\
\hline & & Ee 18 & 0.886 & & & & \\
\hline & & Ee11 & \begin{tabular}{|l}
0.786 \\
\end{tabular} & & & & \\
\hline & & Ee16 & 0.614 & & & & \\
\hline & \begin{tabular}{|l} 
Trait \\
Engagement
\end{tabular} & Ee1 & 0.621 & 0.883 & 0.845 & 0.847 & 0.521 \\
\hline
\end{tabular}


The Journal of Social Sciences Research

\begin{tabular}{l|l|l|l|l|l|l|l}
\hline \multirow{4}{*}{} & Ee2 & 0.772 & & & & \\
\cline { 2 - 7 } & Ee4 & 0.708 & & & & \\
\cline { 2 - 7 } & Ee5 & 0.706 & & & & \\
\cline { 2 - 7 } & Ee7 & 0.754 & & & & \\
\hline & Ee9 & 0.729 & & & & \\
\hline
\end{tabular}

Figure-2. Measurement model results

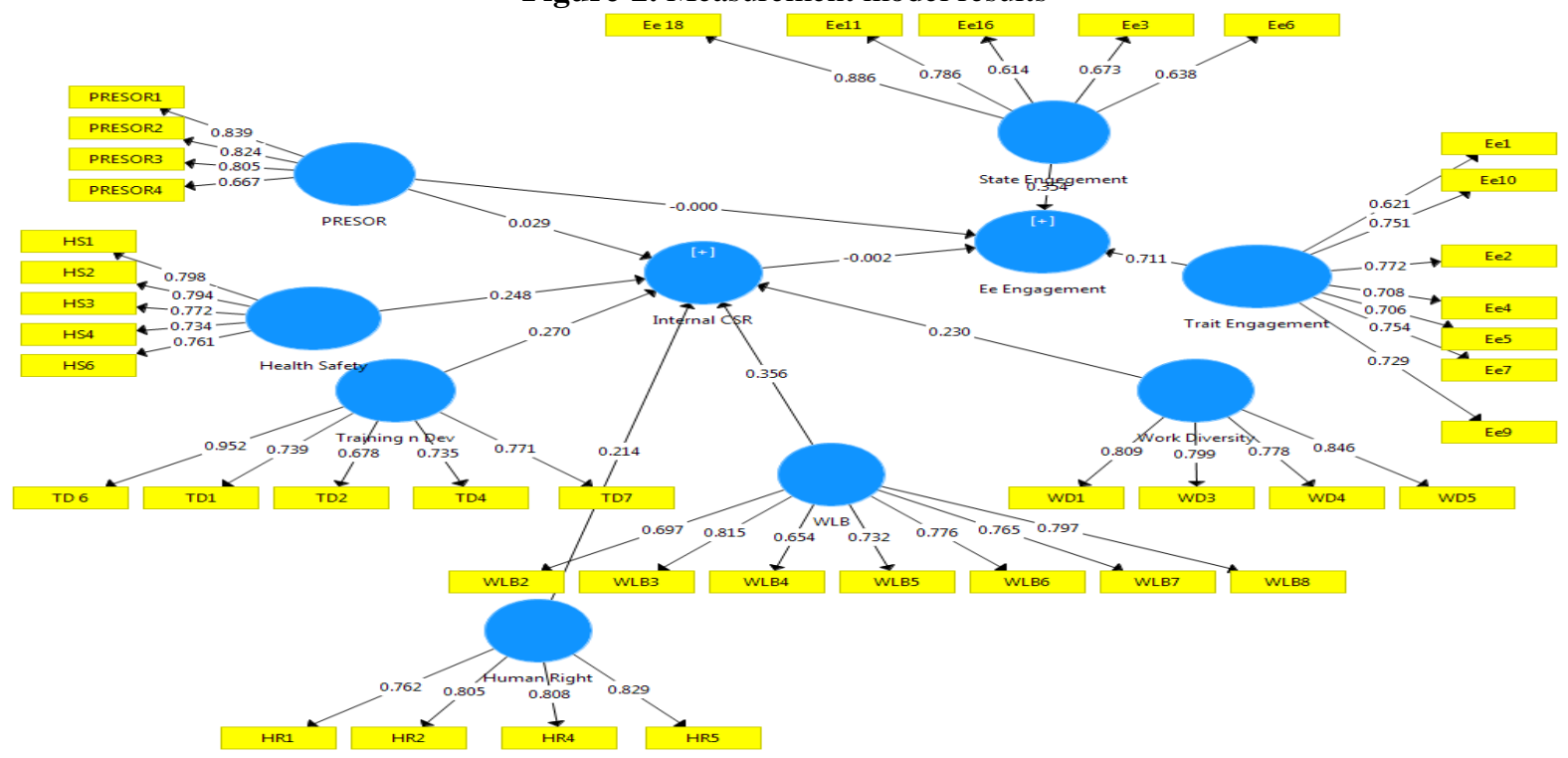

Discriminant validity identifies the degree to which items differentiate among constructs or measure distinct concepts, was examined by following the Fornell and Larcker (1981) criterion by comparing the correlations between constructs and the square root of the average variance extracted for that construct. The results of discriminant validity based on Fornell and Larcker (1981) criterion is shown in Table 3. The results show that all the values on the diagonals were greater than the corresponding row and column values indicating the measures were discriminant. Subsequently, (Henseler et al., 2015) uncovered that the Fornell and Larcker (1981) criterion do not reliably detect the lack of discriminant validity in common research situations. They proposed using the multitraitmultimethod matrix, to assess discriminant validity: the heterotrait-monotrait ratio of correlations (HTMT). As such, HTMT method was adopted to test the discriminant validity and the results are shown in Table 4. If the HTMT value is greater than HTMT0.85 value of 0.85 (Kline, 2011) or HTMT0.90 value of 0.90 (Gold et al., 2001) it indicates a problem of discriminant validity. Table 4 shows all the values passed the HTMT0.90 (Gold et al., 2001) and also the HTMT0.85 (Kline, 2011) hence discriminant validity has been ascertained in the measurement model.

Table-3. Discriminant Validity using Fornell and Larcker (1981) criterion

\begin{tabular}{l|l|l|l|l|l|l|l|l}
\hline & $\begin{array}{l}\text { Health } \\
\text { Safety }\end{array}$ & $\begin{array}{l}\text { Human } \\
\text { Right }\end{array}$ & PRESOR & State Eng & $\begin{array}{l}\text { Training n } \\
\text { Dev }\end{array}$ & Trait Eng & WLB & $\begin{array}{l}\text { Work } \\
\text { Diversity }\end{array}$ \\
\hline Health Safety & $\mathbf{0 . 7 7 2}$ & & & & & & & \\
\hline Human Right & 0.447 & $\mathbf{0 . 8 0 1}$ & & & & & & \\
\hline PRESOR & 0.361 & 0.326 & $\mathbf{0 . 7 8 6}$ & & & & & \\
\hline State Eng & 0.337 & 0.325 & 0.478 & $\mathbf{0 . 7 2 7}$ & & & & \\
\hline Training n Dev & 0.496 & 0.382 & 0.402 & 0.371 & $\mathbf{0 . 7 8 1}$ & & & \\
\hline Trait Eng & 0.361 & 0.423 & 0.441 & 0.728 & 0.387 & $\mathbf{0 . 7 2 2}$ & & \\
\hline WLB & 0.327 & 0.387 & 0.196 & 0.292 & 0.462 & 0.398 & $\mathbf{0 . 7 5 0}$ & \\
\hline Work Diversity & 0.468 & 0.540 & 0.270 & 0.278 & 0.474 & 0.407 & 0.507 & $\mathbf{0 . 8 0 8}$ \\
\hline
\end{tabular}

Note: Diagonal elements are the square root of the AVE of the reflective scales while the off diagonals are the squared correlations between constructs 


\begin{tabular}{l|l|l|l|l|l|l|l|l}
\hline & & Right & & & n Dev & Eng & & Diversity \\
\hline Health Safety & & & & & & & & \\
\hline Human Right & 0.540 & & & & & & & \\
\hline PRESOR & 0.439 & 0.410 & & & & & & \\
\hline State Eng & 0.393 & 0.381 & 0.594 & & & & & \\
\hline Training \& Dev & 0.587 & 0.459 & 0.488 & 0.446 & & & & \\
\hline Trait Eng & 0.431 & 0.508 & 0.544 & 0.860 & 0.454 & & & \\
\hline WLB & 0.378 & 0.448 & 0.233 & 0.356 & 0.533 & 0.466 & & \\
\hline Work Diversity & 0.560 & 0.651 & 0.330 & 0.330 & 0.571 & 0.489 & 0.598 & \\
\hline
\end{tabular}

\subsection{Structural Model Analysis}

In view of the measurement model assessment provides satisfactory quality, we moved on to the second step of PLS-SEM analysis which is the structural model assessment. Prior to structural model analysis, the constructs are checked for potential collinearity issues. Sarstedt et al. (2017) proposed that Variance Inflated Factor (VIF) values 5 are indicative of collinearity among the predictor constructs. The VIF values of constructs are shown in Table 5.0, with all values below 2.5. This concludes the constructs do not suffer from collinearity issues.

Table-5. Checking of Collinearity Issues

\begin{tabular}{l|l}
\hline Construct & VIF \\
\hline Health Safety & 1.571 \\
\hline Human Right & 1.581 \\
\hline Internal CSR & 1.505 \\
\hline PRESOR & 1.275 \\
\hline State Engagement & 2.157 \\
\hline Training n Dev & 1.694 \\
\hline Trait Engagement & 2.450 \\
\hline WLB & 1.495 \\
\hline Work Diversity & 1.815 \\
\hline
\end{tabular}

Upon checking of potential collinearity issues, we begin to focus on the predictive capabilities of the model through structural model analysis. According to S. et al. (2010), structural model denotes the causal relationships among the constructs in the model that includes the estimates of the path coefficients and the $\mathrm{R}^{2}$ value, which determine the predictive power of the model tested. Hair et al. (2017) advised looking at the $\mathrm{R}^{2}$, beta $(\beta)$ and the corresponding t-values via a bootstrapping procedure with a resample of 5,000. Additionally, they also recommended researchers to report the predictive relevance $\left(Q^{2}\right)$ as well as the effect sizes $\left(f^{2}\right)$. Table 6 reports all the direct relationship for hypotheses testing. PRESOR $(\beta=0.029, \mathrm{t}$ value $>1.96, \mathrm{p}$ value $<0.05)$ is positively associated with Internal CSR practices by explaining $99.5 \%$ of the variances in Internal CSR practices. Thus, H1 is supported. However, PRESOR and Internal CSR are not positively associated with Employee Engagement with $t$ value less than 1.96 and $\mathrm{p}$ value higher than 0.05 . Therefore, both $\mathrm{H} 2$ and $\mathrm{H} 3$ are not supported.

Table-6. Hypotheses Testing for Direct Relationship

\begin{tabular}{|c|c|c|c|c|c|c|c|c|}
\hline Hypothesis & Std Beta & Std Error & t-value & $p$ value & Decision & $\mathbf{R}^{2}$ & $Q^{2}$ & \\
\hline $\begin{array}{l}\text { H1: PRESOR is } \\
\text { positively associated } \\
\text { with Internal CSR } \\
\text { practices } \\
\end{array}$ & 0.029 & 0.006 & 4.608 & 0.000 & Supported & 0.995 & 0.302 & 0.001 \\
\hline $\begin{array}{l}\text { H2: PRESOR is } \\
\text { positively associated } \\
\text { with } \text { Employee } \\
\text { Engagement. }\end{array}$ & 0.000 & 0.000 & 0.046 & 0.376 & Not supported & & & \\
\hline $\begin{array}{l}\text { H3: Internal CSR is } \\
\text { positively associated } \\
\text { with Employee } \\
\text { Engagement. }\end{array}$ & -0.002 & 0.007 & 0.362 & 0.362 & Not supported & & & \\
\hline
\end{tabular}

In terms of the indirect relationship which involves mediation, (Preacher and Hayes, 2004;2008)'s guidelines are adopted. According to Preacher and Hayes (2004); Preacher and Hayes (2008) approach, a significant mediation effect is confirmed with no zero value straddle in between 95\% Boot CI. H4 hypothesises that Internal CSR mediates the relationship between PRESOR and Employee Engagement. The beta coefficient for this mediation relationship was recorded as 0.000 with $t$ value at $0.049(\mathrm{p}>0.05)$. The insignificant mediation effect is further confirmed with zero value straddle in between 95\% Boot $\mathrm{CI}$ : $[\mathrm{LL}=-0.014, \mathrm{UL}=0.012]$. Therefore, Hypothesis 4 is not supported.

Table-7. Indirect effect of Internal CSR between PRESOR and Employee Engagement 


\begin{tabular}{l|l|l|l|l|l|l}
\hline Relationship & $\begin{array}{l}\text { Standard } \\
\text { Beta }\end{array}$ & $\begin{array}{l}\text { Standard } \\
\text { error }\end{array}$ & $\begin{array}{l}\boldsymbol{t} \\
\text { value }\end{array}$ & $\begin{array}{l}\boldsymbol{p} \\
\text { value }\end{array}$ & $\begin{array}{l}\text { CIBC } \\
\mathbf{2 . 5 \%}\end{array}$ & $\begin{array}{l}\text { CIBC } \\
\mathbf{9 7 . 5 \%}\end{array}$ \\
\hline $\begin{array}{l}\text { H4: Internal CSR mediates } \\
\text { the relationship between } \\
\text { PRESOR and Employee } \\
\text { Engagement }\end{array}$ & 0.000 & -0.001 & 0.049 & 0.961 & -0.0140 & 0.012 \\
\hline
\end{tabular}

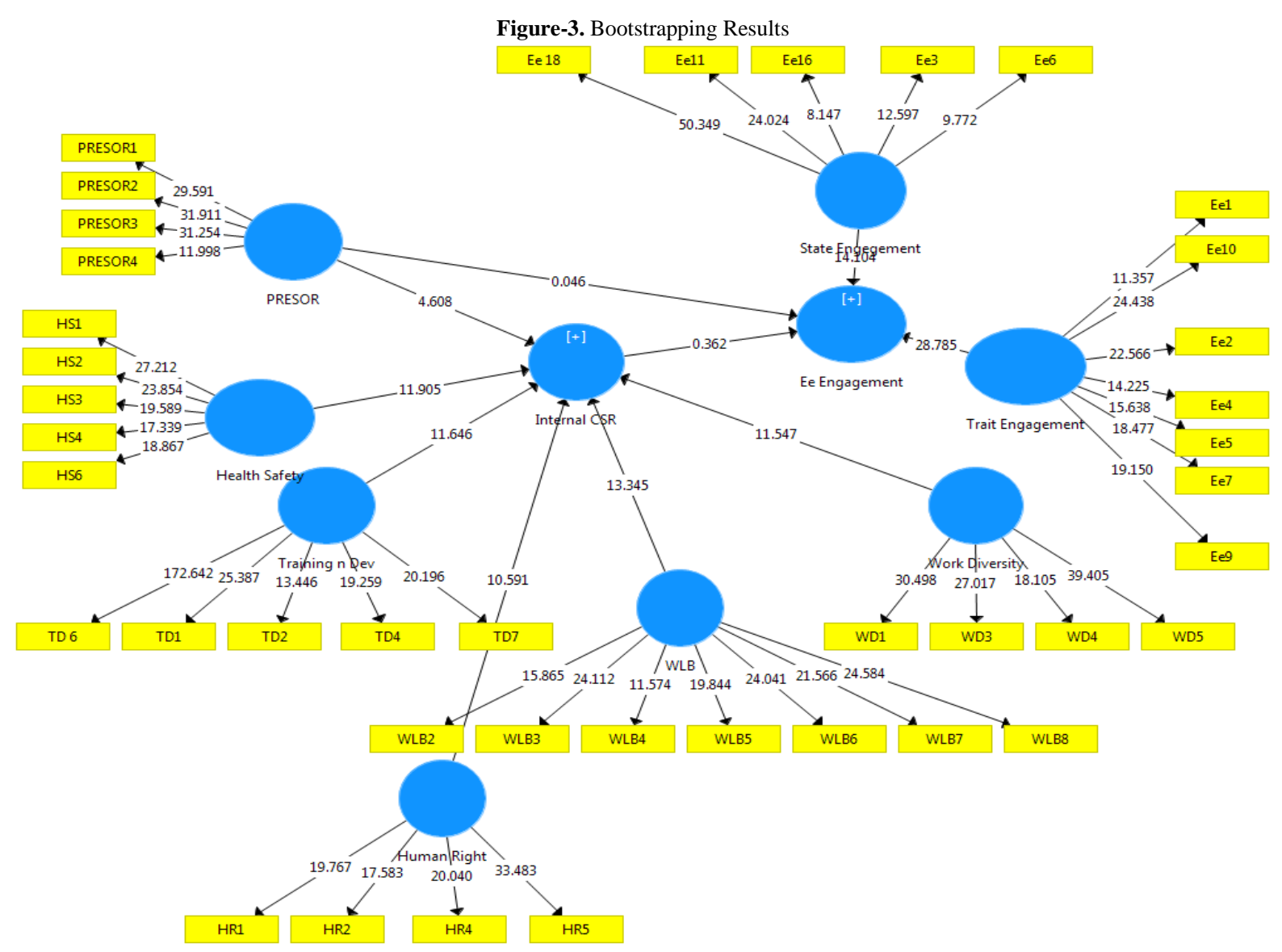

\section{Findings and Discussions}

The findings of this research suggest that PRESOR and Internal CSR are meaningful constructs that worthy of future research in the non-business setting. The results reveal that PRESOR has a positive relationship with Internal CSR practices. This is congruent with PRESOR concept that individuals must first perceive ethics and social responsibility to be vital to organisational effectiveness before their behaviours will become more ethical and reflect greater social responsibility. The findings denote that when an academician values the importance of ethics and social responsibility, they tend to appreciate the implementation of Internal CSR practices in their organisations. This explained the positive association obtained. The results also conform to the results obtained in past research of PRESOR in business organisations (Yin et al., 2016).

The results failed to support Hypothesis 2 indicates that there is no direct positive relationship between PRESOR and Employee Engagement. PRESOR relates to one's perception on the importance of ethics and social responsibility, while Employee Engagement is attitudinal in nature. This shows that an academician may agree that it is important to be ethical and socially responsible, but it does not convert into attitude by being more engaged at work. Accordingly, perception is the process by which individuals interpret and organise sensation to produce a meaningful experience of the world (Lindsay and Norman, 1977). While, attitude is defined as a mental or neural state of readiness, organised through experience, exerting a directive or dynamic influence on the individual's response to all objects and situations to which it is related based on (Allport, 1935). These definitions show that perception and attitudes are related to the cognition and psychology perspectives. Based on these understandings, it explained that an academician interpreted the importance of ethics and social responsibility as vital practices. However, it does not assist in producing an engaged attitude at work, such as committed and motivated at work. These findings inform that there are other possible antecedents to Employee Engagement and PRESOR is not the antecedent. The hypothesis of a positive association between Internal CSR practice and Employee Engagement is also not supported. The possible explanation of the findings is due to the dimensions adopted for Internal CSR practices, namely Training and Development, Human Right, Health and Safety, Workforce Diversity and Work Life Balance, are some existing practices in education. In facts, Subramaniam and (Subramaniam and Selvaratnam, 2010) found out that some public sector, the private sector, and academics in universities are practicing family 
friendly policies, and among others is flexi-working hours. In this regard, the presence of Internal CSR practices does not seem to influence the employee outcomes, particularly employee engagement in this research.

Lastly, the only indirect relationship hypothesised was also found to be not supported. It was uncovered that Internal CSR does not mediate the relationship between PRESOR and Employee Engagement. These findings can be substantiated with a statistical explanation on testing mediation effect. According to (Zhao et al., 2010), the direct effect should be significant if the mediator is excluded in the model. Additionally, (Hair et al., 2017) characterised two types of nonmediation effects, i.e., direct-only nonmediation which the direct effect is significant but not the indirect effect, and no-effect nonmediation which neither the direct nor indirect effect are significant. The present case presented fall into the no-effect nonmediation. The results reveal that there is no direct effect presence in the relationship between PRESOR and Employee Engagement in Hypothesis 2. As such, the mediation effect of Internal CSR is not significant.

Despite that three hypotheses developed for the current research are found to be not supported, present research findings contribute by revealing that PRESOR has a positive association with Internal CSR in the education setting. The findings also suggested that when Internal CSR practices already in existence, it would not have an impact on employee outcomes. If the universities are looking for means to enhance academicians' employee engagement, they should opt for other alternatives besides Internal CSR practices. The results further confirmed the conclusion made by (Zhao et al., 2010) in testing mediation effect that the direct effect shall be significant in order to proceed with mediation testing.

\section{Limitation and Future Research}

Like any other research, current research also suffered some limitations. Firstly, the present research was confined to Peninsular Malaysia and it fails to generalise to the entire population. Secondly, there could be other factors that effecting employee engagement other than the ethics and social responsibilities aspects.

Future research is recommended to be expanded to the whole of Malaysia by including universities located in Sabah and Sarawak. It is also proposed to conduct a probability sampling method if the list of academician in the universities is available. Future research may adopt triangulation approach in order to collect more in-depth information and perception from respondents pertaining to PRESOR and Internal CSR. In terms of employee engagement, future research could explore other organisational behaviour constructs such as perceived organisational support and leadership.

\section{References}

Akter, S., D'Ambra, J. and Ray, P. (2011). Trustworthiness in health information services.

Allport, G. W. (1935). Attitudes, In Murchison C. (Ed.), Handbook of social psychology, Worcester. Clark University Press: Worcester, MA. 798-844.

Anderson, J. C. and Gerbing, D. W. (1988). Structural equation modeling in practice, A review and recommended two-step approach. Psycho Bulletin, 103(3): 411-23.

Anon (2017). Available at, Knowledge-based economy Malaysia (master plan). Available: http://unpan1.un.org/intradoc/groups/public/documents/APCITY/UNPAN013975.pdf

Axinn, C. N., Blair, E., Alla, H. and Sharon, V. T. (2004). Comparing ethical ideologies across cultures. Journal of Business Ethics, 54(2): 103-19.

Bates, S. (2004). Getting engaged, HR magazine. 49(2): 44-51.

Baumruk, R. (2004). The missing link, The role of employee engagement in business success. Workspan. 47: 48-52.

Bochenek, M., Kingston-Mann, E. and Sieber, T. (2002). Achieving against the odds, How academics become teachers of diverse students. Teaching Sociology, 30(1): 122.

Boddy, C. R. (2011). Corporate psychopaths, bullying and unfair supervision in the workplace. Journal of Business Ethics, 100(3): 367-79.

Cain, M. K., Zhang, Z. and Yuan, K. H. (2016). Univariate and multivariate skewness and kurtosis for measuring nonnormality, Prevalence, influence and estimation. Behaviour Research Methods:

Carroll, A. (1999). Corporate social responsibility. Business \& Society, 38(3): 268-95.

Churchill, L. R. (1982). The teaching of ethics and moral values in teaching, Some contemporary confusions. The Journal of Higher Education, 53(3): 296-306.

Demirtas, O. and Akdogan, A. (2015). The effect of ethical leadership behaviour on ethical climate, turnover intention, and affective commitment. Journal of Business Ethics, 130(1): 59-67.

Erickson, T. J. (2005). Testimony submitted before the u.S. Senate committee on health, education. Labor and Pensions, 26.

Faul, F., Erdfelder, E., Lang, A.-G. and Buchner, A. (2007). G*power 3, A flexible statistical power analysis program for the social, behavioural, and biomedical sciences. Behaviour Research Methods, 39: 175-91.

Faul, F., Erdfelder, E., Buchner, A. and Lang, A.-G. (2009). Statistical power analyses using g*power 3.1, Tests for correlation and regression analyses. Behaviour Research Methods, 41: 1149-60.

Fornell, C. G. and Larcker, D. F. (1981). Evaluating structural equation models with unobservable variables and measurement error. Journal of Marketing Research, 18(1): 39-50.

Gefen, D., Rigdon, E. E. and Straub, D. (2011). An update and extension to sem guidelines for administrative and Social Science Research. MIS Quarterly, 35(2): 3.A7.

Gholami, R., Sulaiman, A. B., Ramayah, T. and Molla, A. (2013). Senior managers' perception. 
Glavas, A. and Piderit, S. K. (2009). How does doing good matter? Effects of corporate citizenship on employees. Journal of Corporate Citizenship, 36: 51-70.

Gold, A. H., Malhotra, A. and Segars, A. H. (2001). Knowledge management, An organizational capabilities perspective. Journal of Management Information Systems, 18(1): 185-214.

Hair, J. F., Hult, G. T. M., Ringle, C. M. and Sarstedt, M. (2017). A primer on partial least squares structural equation modeling. 2nd edn: Sage: Thousand Oaks.

Harter, J. K., Schmidt, F. L. and Hayes, T. L. (2002). Business-unit level relationship between employee satisfaction, employee engagement, and business outcomes, A meta-analysis. Journal of Applied Psychology, 87: 26879.

Henseler, J., Ringle, C. M. and Sarstedt, M. (2015). A new criterion for assessing discriminant validity in variancebased structural equation modelling. Journal of the Academy of Marketing Science, 43(1): 115-35.

Hewitt Associates, L. (2005). Employee engagement higher at double-digit growth companies. Research Brief. 1-6.

Kalayanee, K., Singhapakdi, A., Virakul, B. and Lee, D. J. (2010). Ethics institutionalization, quality of work life, and employee job-related outcomes, A survey of human resource managers in Thailand. Journal of Business Research, 63(1): 20-26.

Kline, R. B. (2011). Principles and practice of structural equation modeling. Guilford Press: New York.

Larsen, R. J., Diener, E. and Lucas, R. E. (2002). Emotion models, Measures, And individual differences. In r. G. Lord, r. J. Klimoski, \& r. Kanfer (eds.), Emotions in the workplace. Jossey-Bass: San Francisco. 64 - 106.

Lindsay, P. and Norman, D. A. (1977). Human information processing, An introduction to psychology. Harcourt Brace Jovanovich, Inc.

Low, M. P. (2015). Corporate social responsibility and the evolution of internal corporate.

Macey, W. H. and Schneider, B. (2008). The meaning of employee engagement. Industrial And Organizational Psychology, 1(1): 3-30.

Malle, B. F. (2003). Folk theory of mind, Conceptual foundations of social cognition." in hassan, uleman, \& bargh (eds.), the new unconscious. Oxford University Press. $1-29$.

Marta, J. K. M., Singhapakdi, A., Attia, A. and Vitell, S. J. (2004). Some important factors underlying ethical decisions of middle-eastern marketers. International Marketing Review, 21(1): 53-67.

Mory, L., Wirtz, B. W. and Göttel, V. (2016). Corporate social responsibility strategies and their impact on employees' commitment. Journal of Strategy and Management, 9(2): 172-201.

Podsakoff, P. M., MacKenzie, S. B., Lee, J.-Y. and Podsakoff, N. P. (2003). Common method biases in behavioral research, A critical review of the literature and recommended remedies. Journal of Applied Psychology, 88(5): 879-903.

Preacher, K. J. and Hayes, A. F. (2004). SPSS and SAS procedures for estimating indirect effects in simple mediation models. Behaviour Research Methods, Instruments, \& Computers, 36(4): 717-31.

Preacher, K. J. and Hayes, A. F. (2008). Asymptotic and resampling strategies for assessing and comparing indirect effects in multiple mediator models. Behaviour Research Methods, 40(3): 879-91.

Rahman, S. A., Amran, A., Ahmad, N. H. and Taghizadeh, S. K. (2015). Supporting entrepreneurial business success at the base of pyramid through entrepreneurial competencies. Management Decision, 53(6): 120323.

Reinartz, W., Haenlein, M. and Henseler, J. (2009). An empirical comparison of the efficacy.

Richman, A. (2006). Everyone wants an engaged workforce how can you create it. Workspan. 49: 36-39.

Ringle, C. M., Marko, S. and Detmar, W. S. (2012). Editor's comments: A critical look at the use of pls-sem in mis quarterly. MIS Quarterly, 36(1): 3-16.

S., S., Lee, J. D. and Lee, J. (2010). E-government adoption in cambodia, A partial least squares approach. In, Transforming government, People, process, and policy. Emerald Group Publishing Limited, Bingley, 4(2): 138-57.

Sarstedt, M., Ringle, C. and Hair, J. F. (2017). Partial least squares structural equation modeling, Homburg, et al. In handbook of marketing research. Springer International Publishing. 1-40.

Shafer, W. E., Kyoko, F. and Grace, M. L. (2007). Values and the perceived importance of ethics and social responsibility, The us versus China. Journal of Business Ethics, 70(3): 265-84.

Singhapakdi, A. (1999). Perceived importance of ethics and ethical decisions in marketing. Journal of Business Research, 45(1): 89-99.

Singhapakdi, A., Kraft, K. L., Vitell, S. J. and Rallapalli, K. C. (1996). The perceived importance of ethics and social responsibility on organizational effectiveness, A survey of marketers. Journal of the Academy of Marketing Science, 23(1): 49-56.

Singhapakdi, A., Karande, K., Rao, C. and Vitell, S. (2001). How important are ethics and social responsibility? - A multinational study of marketing professionals. European Journal of Marketing, 35(1/2): 133-53.

Singhapakdi, A., Gopinath, M., Marta, J. K. and Carter, L. L. (2008). Antecedents and consequences of perceived importance of ethics in marketing situations, A study of thai businesspeople. Journal of Business Ethics, 81(4): 887-904.

Subramaniam, G. and Selvaratnam, D. P. (2010). Family friendly policies in Malaysia, Where are we. Journal of International Business Research, 9(1): 43-120.

Turker, D. (2009a). How corporate social responsibility influences organizational commitment. Journal of Business Ethics, 89(2): 189-204. 
Turker, D. (2009b). Measuring corporate social responsibility, A scale development study`. Journal of Business Ethics, 85(4): 411-27.

Vitell, S. J. and Joseph, G. P. (2004). A cross-cultural study of the antecedents of the perceived role of ethics and social responsibility. Business Ethics, A European Review, 13(2-3): 185-99.

Vitell, S. J., Encarnación, R. and Ceri, M. N. (2010). The role of ethics and social responsibility in organizational success, A spanish perspective. Journal of Business Ethics, 91(4): 467-83.

Vives, A. (2006). Social and environmental responsibility in small and medium enterprises in latin America. Journal of Corporate Citizenship, 21: 39-50.

Weiss, H. M. (2002). Deconstructing job satisfaction, Separating evaluations, beliefs and affective experiences. Human Resource Management Review, 12: 173-94.

Wetzels, M., Odekerken-Schröder, G. and Van, O. C. (2009). Using PLS path modeling for assessing hierarchical construct model, Guidelines and empirical illustration. MIS Quarterly: 177-95.

Wotruba, T. R. (1997). Industry self-regulation, A review and extension to a global setting. Journal of Public Policy \& Marketing: 38-54.

Yin, J., Singhapakdi, A. and Du, Y. (2016). Causes and moderators of corporate social responsibility in China, The influence of personal values and institutional logics. Asian Business \& Management, 15(3): 226-54.

Zhao, X., Lynch, J. J. G. and Chen, Q. (2010). Reconsidering baron and kenny, Myths and truths about mediation analysis. Journal of consumer research, 37(2): 197-206. 